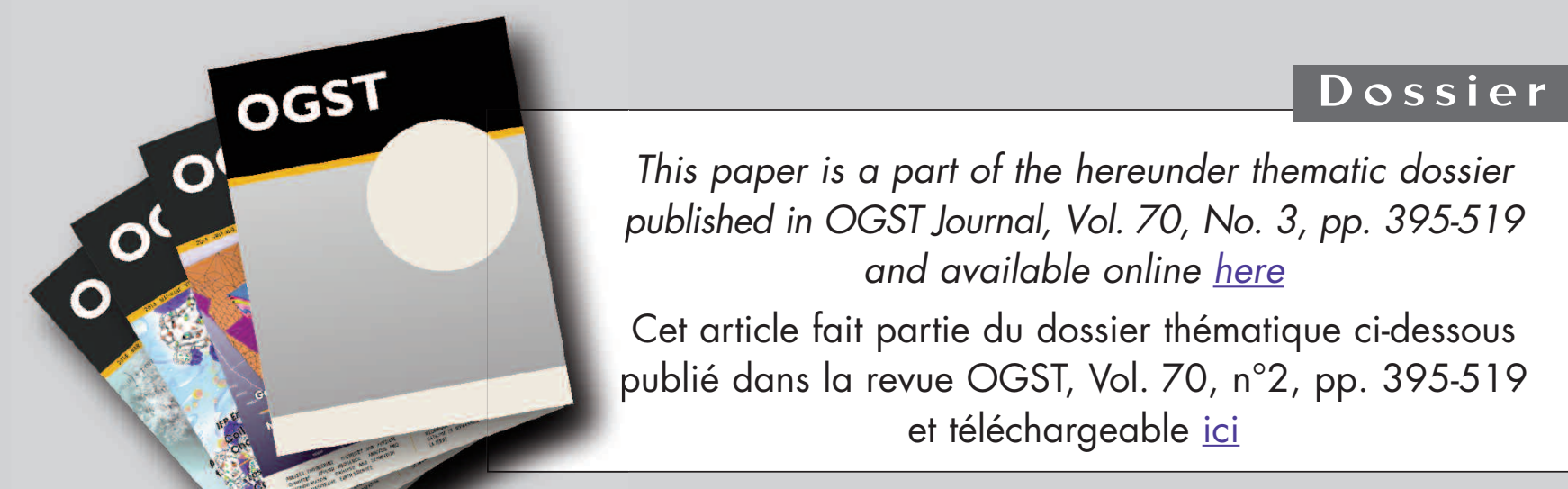

DOSSIER Edited by/Sous la direction de : V. Santos-Moreau

IFP Energies nouvelles International Conference / Les Rencontres Scientifiques d'IFP Energies nouvelles NEXTLAB 2014 - Advances in Innovative Experimental Methodology or Simulation Tools used to Create, Test, Control and Analyse Systems, Materials and Molecules

NEXTLAB 2014 - Innover dans le domaine de la méthodologie expérimentale et des outils de simulation pour créer, tester, contrôler et analyser des systèmes, matériaux et molécules

Oil \& Gas Science and Technology - Rev. IFP Energies nouvelles, Vol. 70 (2015), No. 3, pp. 395-519

Copyright (C) 2015, IFP Energies nouvelles

$395>$ Editorial - Towards the Laboratory of the Future for the Factory of the Future Éditorial - Vers le laboratoire du futur pour construire l'usine du futur V. Santos-Moreau, J.M. Newsam and J.-C. Charpentier

$405>$ Automatic and Systematic Atomistic Simulations in the MedeA ${ }^{\circledR}$ Software Environment: Application to EU-REACH

Simulations atomistiques automatiques et systématiques dans l'environnement logiciel de MedeA® : application à EU-REACH

$X$. Rozanska, P. Ungerer, B. Leblanc, P. Saxe and E. Wimmer

419 > Development of an Innovative XRD-DRIFTS Prototype Allowing Operando Characterizations during Fischer-Tropsch Synthesis over Cobalt-Based Catalysts under Representative Conditions

Développement d'un prototype DRX-DRIFTS innovant permettant des caractérisations operando de catalyseurs à base de cobalt pendant la synthèse de Fischer-Tropsch en conditions représentatives

J. Scalbert, I. Clémençon, C. Legens, F. Diehl, D. Decottignies and S. Maury

429 > Synchrotron X-ray Scattering as a Tool for Characterising Catalysts on Multiple Length Scales

La diffusion des rayons $X$ synchrotron : un outil pour la caractérisation des catalyseurs sur les multiples échelles de longueur

J.M. Hudspeth, K.O. Kvashnina, S.A.J. Kimber and E.P. Mitchell

437 > High Throughput Experimentation (HTE) Directed to the Discovery,

Characterization and Evaluation of Materials

Expérimentation à haut débit pour la découverte, la caractérisation et

l'évaluation des matériaux

J.M. Newsam

447 > The Use of Original Structure-Directing Agents for the Synthesis of EMC-1 Zeolite L'utilisation d'agents structuraux originaux pour la synthèse de zéolithe EMC-1

T.J. Daou, J. Dhainaut, A. Chappaz, N. Bats, B. Harbuzaru, H. Chaumeil, A. Defoin,

L. Rouleau and J. Patarin
455 > REALCAT: A new Platform to Bring Catalysis to the Lightspeed REALCAT : une nouvelle plate-forme pour mener la catalyse à la vitesse de la lumière

S. Paul, S. Heyte, B. Katryniok, C. Garcia-Sancho, P. Maireles-Torres and F. Dumeignil

$463>$ What are the Needs for Process Intensification? Quels besoins pour intensifi er un procédé ?

C. Gourdon, S. Elgue and L. Prat

$475>$ Revisiting the Side Crushing Test Using the Three-Point Bending Test for the Strength Measurement of Catalyst Supports

Test d'écrasement grain à grain revisité à l'aide du test de flexion trois points pour la mesure de la résistance des supports de catalyseurs D. Staub, S. Meille, V. Le Corre, J. Chevalier and L. Rouleau

487 > Refractometric Sensing of Heavy Oils in Fluorescent Core Microcapillaries La détection réfractométrique des huiles lourdes dans les microcapillaires à cœur fluorescents

V. Zamora, Z. Zhang and A. Meldrum

497 > Two-Phase Flow in Pipes: Numerical Improvements and Qualitative Analysis for a Refining Process

Écoulements diphasiques dans les conduites : améliorations numériques et analyse qualitative pour un procédé de raffinage

R.G.D. Teixeira, A.R. Secchi and E.C. Biscaia Jr

511 > Comparative TPR and TPD Studies of Cu and Ca Promotion on Fe-Zn- and Fe-Zn-Zr-Based Fischer-Tropsch Catalysts

Études comparatives par TPR et TPD de la promotion par Cu et Ca de I'activité de catalyseurs Fischer-Tropsch Fe-Zn et Fe-Zn-Zr 0.0 . James, B. Chowdhury and S. Maity 


\title{
What are the Needs for Process Intensification?
}

\author{
Christophe Gourdon*, Sébastien Elgue and Laurent Prat \\ University of Toulouse, Laboratoire de Génie Chimique, LGC UMR 5503 CNRS/INPT/UPS, 31432 Toulouse - France \\ e-mail: christophe.gourdon@ensiacet.fr - sebastien.elgue@ensiacet.fr - laurent.pra@@ensiacet.fr \\ * Corresponding author
}

\begin{abstract}
Process intensification is now well known among the world of chemical engineers. The development of new chemical routes and of innovative modular technologies may lead to some breakthrough progress. Some successful stories have been nowadays demonstrated. Particularly, batch-to-continuous is one of the key issues for intensifying processes. But, the need of process intensification requires the need of collecting many new data of high quality relative to the chemical reaction and to the equipment as well, which represents sometimes a huge effort. This discussion is the opportunity to review the basic data and the metrology associated for the characterization of applications and technologies in order to guide the design of the intensified process. Concerning the chemicals, the stoechio-kinetics parameters, the phase equilibria data (for instance solubility) or the reaction enthalpies can be efficiently determined thanks to microfluidic devices. Concerning the equipment, benchmark studies have to be performed in view of comparing the technologies according to pressure drop, residence time distribution, heat and mass transfer performances, mixing efficiencies and so on. A way of capitalizing the background knowledge lies on simulation tools development, here called data processing tool. This presentation intends also to introduce some of the European network tools developed for diffusing the methodology of intensification, like the industrial club EUROPIC (European Process Intensification Centre) and the demonstration platform MEPI (Maison Européenne des Procédés Innovants).
\end{abstract}

Résumé - Quels besoins pour intensifier un procédé ? - L'intensification des procédés est un concept désormais bien répandu au sein de la communauté du génie des procédés. Le développement de nouvelles voies chimiques et de technologies novatrices peut parfois conduire à des innovations de rupture. Il en a résulté un certain nombre de réussites industrielles. En particulier le passage batchcontinu est une des voies privilégiées pour intensifier un procédé. Mais si l'intérêt de l'intensification n'est plus à démontrer, il n'en demeure pas moins qu'elle nécessite d'acquérir un grand nombre de données relatives aussi bien à la voie chimique qu'au type d'équipement envisagé, ce qui représente un effort considérable. Cet article fait le point sur les données de base à acquérir et la métrologie associée pour concevoir un procédé intensifié. En ce qui concerne l'application chimique, on peut alors avoir recours aux outils microfluidiques pour acquérir de manière fiable et rapide les informations stoechiocinétiques et enthalpiques. En ce qui concerne l'équipement, des méthodes standards permettent de comparer les performances de diverses technologies en matière de perte de charge, distribution de temps de séjour, transferts de matière et de chaleur, mélange, etc. Une manière efficace de capitaliser la connaissance passe par le développement d'outil de simulation, baptisé ici data processing tool. L'article met également en exergue le besoin de mettre en place des outils de diffusion de la connaissance, comme par exemple le réseau EUROPIC (European Process Intensification Centre) et la plateforme de démonstration industrielle MEPI (Maison Européenne des Procédés Innovants). 


\section{INTRODUCTION}

Process Intensification (PI) is now well known among the world of chemical engineers (Stankiewicz and Moulijn, 2003; Cybulski et al., 2011; Reay et al., 2013; Boodhoo and Harvey, 2013). The development of new chemical routes and of innovative modular technologies may lead to some breakthrough progress (European Process Intensification Roadmap, 2007). Some successful stories have been nowadays demonstrated. Particularly, batch-to-continuous is one of the key issues for intensifying processes (Hellier et al., 2010; Anxionnaz et al., 2010; Elgue et al., 2012; Shen et al., 2014; Martin et al., 2014).

But, the need for process intensification requires the need for collecting many new data of high quality relative to the chemical reaction and to the equipment as well, which represents sometimes a huge effort. This requirement imposes to make some innovative advances in experimental, methodology or simulation tools. Not only the process has to be intensified but also the process design methodology.

We intend in this paper to present the methodology of process intensification followed in our lab and to review the basic data and the metrology associated for the characterization of applications and technologies in order to guide the design of the intensified process.

\section{PROCESS INTENSIFICATION}

\subsection{Definition}

Since the $80 \mathrm{~s}$, there is an impressive number of definitions diverse and various of the PI concept (Ramshaw and Arkley, 1983; Cross and Ramshaw, 1986; Stankiewicz and Moulijn, 2000; Tsouris and Porcelli, 2003; Charpentier, 2007; Van Gerven and Stankiewicz, 2009). If one refers to one of the last definitions, proposed during the elaboration of the European Roadmap of Process Intensification in 2007, which expresses itself in the following way: "Process Intensification (PI): a set of often radically innovative principles ("paradigm shift") in process and equipment design, which can bring significant (more than factor 2) benefits in terms of process and chain efficiency, capital and operating expenses, quality, wastes, process safety", it is easy to notice that this definition bases more on the notion of breakthrough than of incremental innovation. We could try to summarize this objective in the following way: PI simply means "using much LESS to produce MUCH more and BETTER", in which "less" is related to investment, space, time, raw materials, energy, inventory, and so on, and "much" refers to factors or orders of magnitude.

This is indeed an attractive slogan, but very requiring and challenging.

\subsection{Challenges Linked to Process Intensification}

What are the challenges linked to PI? There is a need to identify where the limiting steps are exactly located in the process: is this chemistry, transport phenomena, or equipment?

Therefore, it is required to perform an accurate diagnosis of the process. If the process is chemistry dependent (called the chemical regime), the key issues are catalysis, or new chemical routes or new operating windows (temperature, pressure, concentration).

If it is transport phenomena dependent (called the diffusional regime for heat or mass transfer), the key issue is linked to technology or, possibly to new operating windows.

Facing these challenges, PI appears as a kind of tool box for the engineer, essentially based either on equipment (hardware) or on methods (software) leading to different technological solutions with a large variety of examples of technologies or combined technologies. Given this diversity, it becomes necessary to develop a methodology in process intensification to help the engineer to make the optimal choice according to his own application. Some first attempts begin to emerge (Prudhomme et al., 2013; Commenge and Falk, 2014). We describe in what follows the principle of the methodology that we advocate.

\subsection{Process Intensification Methodology}

The issue is therefore to find what could be the optimal solution in relation to the process involved. Clearly, a methodology is needed.

From our point of view, this methodology should be based on two blocks (Fig. 1):

- one dedicated to the equipment qualification and to the technology selection;

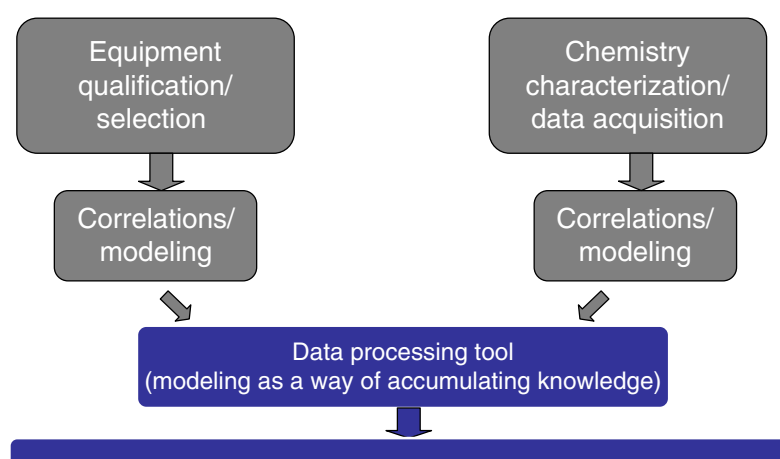

Simulation/optimization/process design/piloting/selection

Figure 1

Process intensification methodology. 
- the other linked to the chemical path characterization and more generally to the basic data acquisition (phase equilibria for instance).

Furthermore, via correlations or modeling, it is then possible to feed a generic simulation tool, called here Data Processing Tool (DPT). This modeling step may be considered as a way to capitalize the knowledge. The deliverables of such a simulation tool can be process simulation, optimization and design and why not piloting and aid to equipment selection.

\section{DATA PROCESSING TOOL (DPT)}

\subsection{Modeling Background}

The role of the modeling is to reproduce and predict the behaviour of any intensified process, according to the operating conditions. From that viewpoint, the description of the equipments must be as true to life as possible. For instance, focusing on Heat-EXchanger (HEX) reactors (Elgue et al., 2007), a realistic description based on a modular structure has been adopted (Fig. 2). This kind of structure built by the stacking of different plates allows various configurations to be described whatever the type of reactor is in terms of size, flow rate, flow configuration and material.

In that case, the reactor is assumed to be similar to a continuous reactor with heat transfer taking place through the walls. Flow modeling is therefore based on the same hypothesis as the one used for the modeling of a real continuous reactor (Villermaux, 1985; Naumann, 2002), represented by a series of Continuous Stirred Tank Reactors (CSTR). This approach is related to the experimental residence time distribution which allows flow analysis (highlighting of dead volumes, preferential passages or short-cuts). Such description makes it very easy to represent all possible flow configurations of the reactor (co-current, counter current). In fact, it implies that the behaviour of a cell depends solely on the inlet streams and on phenomena taking place inside: reaction, heat transfer, etc. Since the inlets of a given cell are generally the outlets of the preceding cell, any flow configuration may be represented by a correct discretization, i.e. the determination of the cell that precedes (Fig. 3).

Given the specific geometry of the reactor, two main parts may be distinguished. The first part is associated with the "process plate" where complex phenomena coupled with reactions occur. The second part encompasses the rest of the reactor structure, involving "utility" fluid, plate wall, etc.

The dynamic modeling of a cell is based on the expression of time-dependent balances (mass and energy) and on constraint equations. The constraint equations are used to take into account the geometrical characteristics of the reactor and the physical properties of the medium considered. The balances may be used to describe the evolution of the characteristic values: temperature, composition, pressure according to the following dynamic formulation:

$$
\begin{aligned}
\{\text { Accumulation flow }\} & =\{\text { Inlets }\}-\{\text { Outlet }\} \\
& +\{\text { Production flow }\}
\end{aligned}
$$

The model involves numerous related correlations which describe the equipment characteristics: residence time distribution, pressure drop, heat transfer, mixing, etc. These correlations are developed, to a large extent, from the specific experimental studies and make it possible to capitalize the knowledge acquired on a given equipment. For the physical properties estimation, the model is connected to BibPhy $\left(\right.$ Prosim $\left.^{\circledR}\right)$ a complete physical property calculation system with an associated data bank.

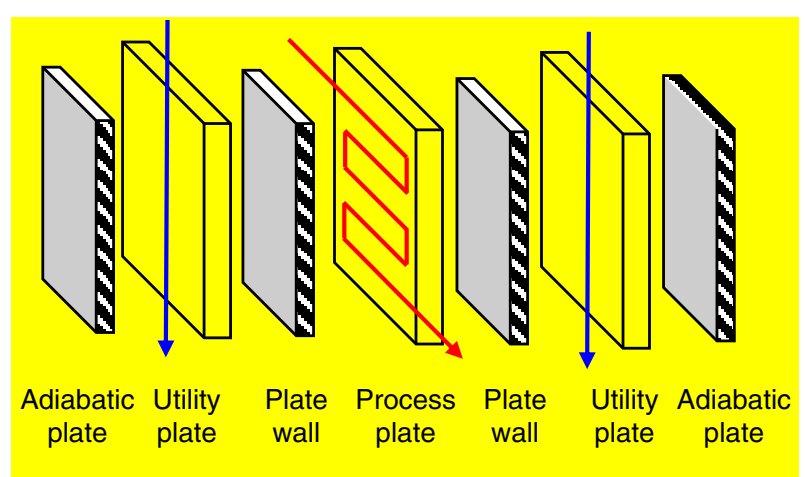

Figure 2

HEX-reactor modeling description.

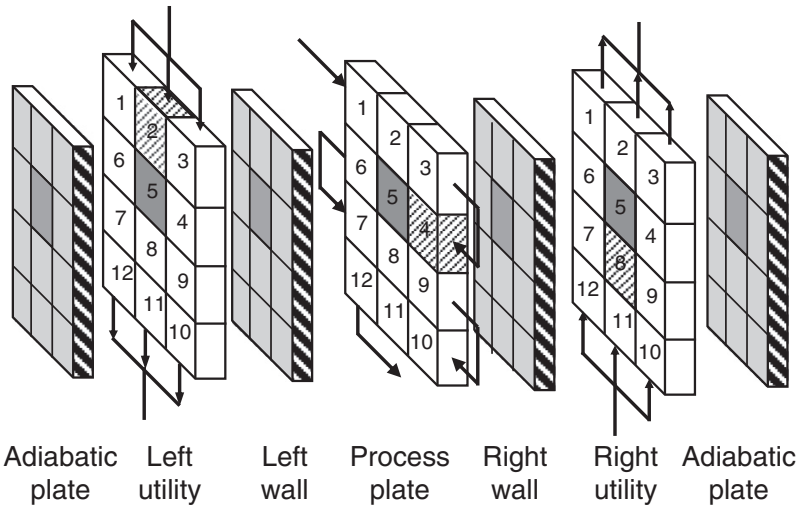

Figure 3

Discretization of a HEX-reactor according to the flow configuration. 


\subsection{Some Examples of Simulation Results}

\subsubsection{A Process Insight}

Thanks to modeling and simulation, it is possible to better understand and predict the process operation.

For several years in our lab (Prat et al., 2005; Benaïssa et al., 2008a, b), a reaction of oxidation has been used as a test reaction to be able to compare the performances of different continuous intensified technologies. The test reaction is the sodium thiosulfate oxidation, a fast reaction exhibiting a strong exothermicity (Lo and Cholette, 1972):

$$
2 \mathrm{Na}_{2} \mathrm{~S}_{2} \mathrm{O}_{3}+4 \mathrm{H}_{2} \mathrm{O}_{2} \rightarrow \mathrm{Na}_{2} \mathrm{~S}_{3} \mathrm{O}_{6}+\mathrm{Na}_{2} \mathrm{SO}_{4}+4 \mathrm{H}_{2} \mathrm{O}
$$

with $\Delta H r=-586.2 \mathrm{~kJ} \cdot \mathrm{mol}^{-1}$ of $\mathrm{Na}_{2} \mathrm{~S}_{2} \mathrm{O}_{3}$.

The reaction scheme and kinetics model have been implemented into the DPT, subsequently it is possible to simulate the temperature and concentration profiles along any type of reactor.

For instance, Figure 4 shows the simulated temperatures and conversion profiles from the inlet (left) to the outlet (right) inside a G1 Corning ${ }^{\circledR}$ Advanced-Flow ${ }^{\mathrm{TM}}$ reactor.

The simulation results highlight the accuracy of modeling with respect to both temperatures and reaction yield. Such accuracy is all the more interesting in that in this application, the heat transfer and reaction aspects are strongly connected, due to the high degree of exothermicity. In the case of G1 Corning $^{\circledR}$ Advanced-Flow ${ }^{\mathrm{TM}}$ reactor, where heat transfer performances are enhanced, a very high reaction sensitivity to cooling is observed: the yield and heat generated are directly related to the utility fluid conditions. For instance, utility temperature has to be set above $50^{\circ} \mathrm{C}$ to be able to reach high conversion level in the given short residence time (only one reactor plate). Such a sensitivity is described very

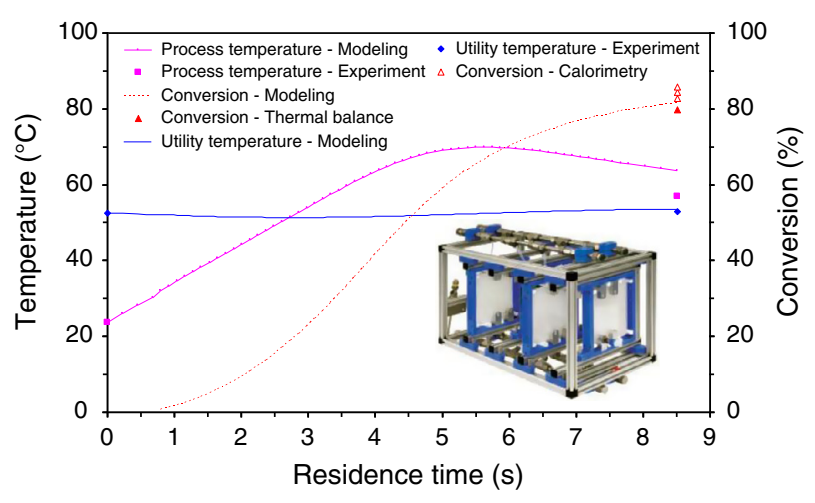

Figure 4

Temperatures (process and utility) and conversion profiles along the reactor. accurately by the simulations, that allow internal temperature profiles to be estimated in an equipment where internal thermocouples cannot be implemented. DPT then offers a better understanding of the process and interesting perspectives from a safety viewpoint (detection of hotspots, of reactants accumulation, of bad mixing, etc.) particularly for applications presenting high dynamics and kinetics and for technologies where it is no easy to put sensors in.

\subsubsection{A Way for Process Design and Management}

By simulation based on the use of the DPT, it is also possible to look for the optimal design aiming at $100 \%$ conversion.

As an example, Figure $5 \mathrm{~b}$ gives the temperatures and conversion profiles in an Alfa-Laval HEX-reactor prototype, the Open Plate Reactor (OPR) (the precursor of the Alfa-Laval $A R T^{\circledR}$ Plate Reactor - Fig. 5a). The reactor design (number of plates) has been simulated in order to ensure at the reactor outlet the goal of $100 \%$ conversion.

The simulated process temperature in Figure $5 \mathrm{~b}$ seems to exhibit a probable hot spot occurring inside the reactor close to the inlet of reactants. Consequently, thanks to DPT, it is possible to examine now what should be the optimal operation of the reactor in order to avoid any hot spot. Figure $5 \mathrm{c}$ shows the result obtained by playing on $R$, which is the ratio of utility flow rate over process flow rate. It is evident that the larger the ratio is, better is the process temperature profile inside the reactor.

In conclusion, DPT may be considered as a process optimization tool not only for the design but also for the operation control and management.

\subsubsection{A Way for Equipment Selection}

Thanks to DPT and simulation of the temperature and conversion profiles, it is possible to compare different technologies between themselves, like in a benchmark challenge. As illustration, here again the Alfa Laval open plate prototype, made of stainless steel and PEEK, and an innovative prototype developed in our laboratory, made of Silicon Carbide ( $\mathrm{SiC}$ ) called Boostec (the name of the SME manufacturer).

With the same operating conditions involving the sodium thiosulfate oxidation (fast and strong exothermicity), Figure 6 shows the temperatures and conversion profiles along both prototypes: Figure 6a relative to the Alfa-Laval technology, Figure $6 \mathrm{~b}$ relative to the Boostec technology. Clearly, because of the reactor material, the temperatures profiles differ radically. The Boostec reactor, thanks to the good thermal effusivity of the $\mathrm{SiC}$ (Cabassud and Gourdon, 2010; Despènes et al., 2012), allows operating quite isothermally. It is not the objective here to go further into the comparison between both technologies, since other criteria should be obviously examined. 
a)
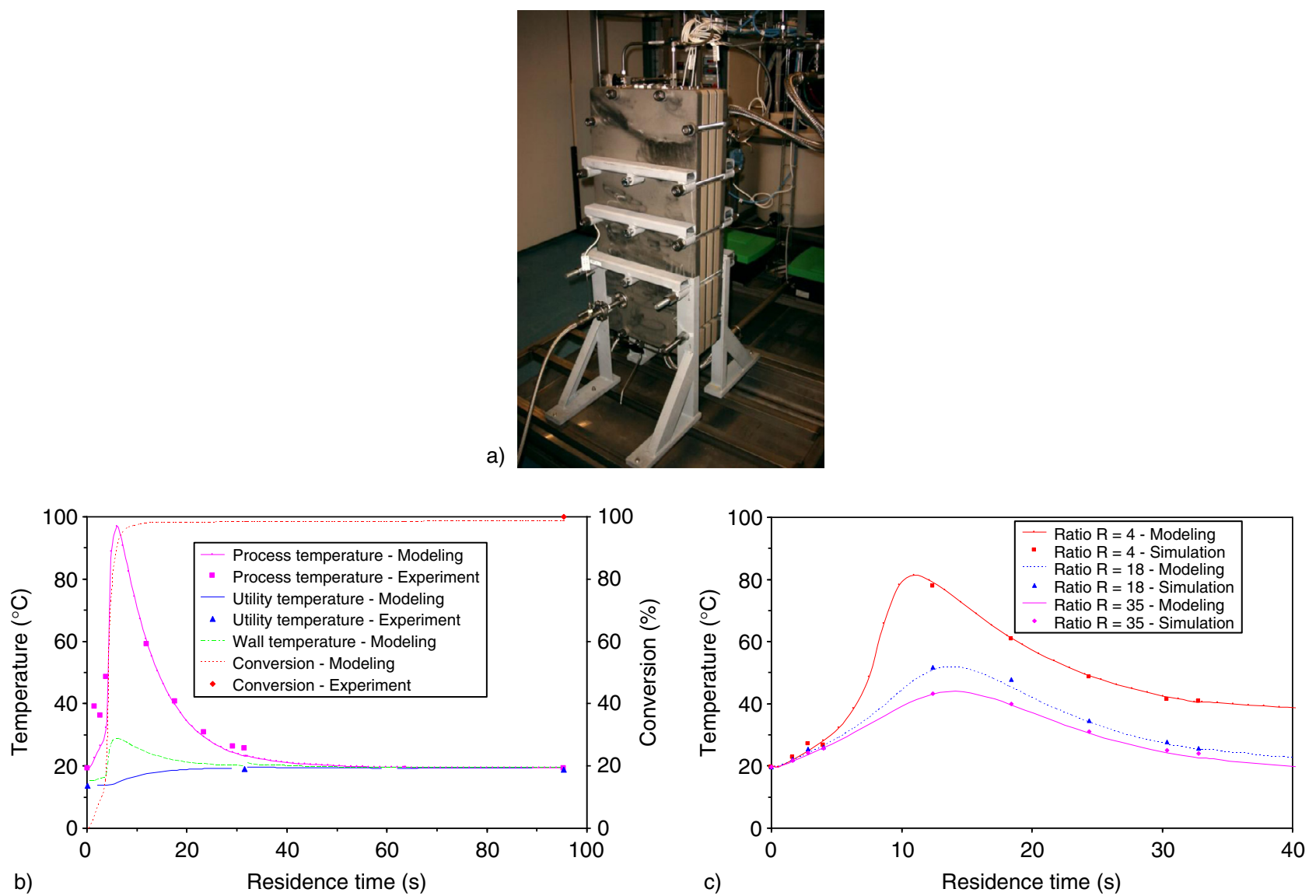

Figure 5

a) Alfa-Laval OPR; b) temperatures (process and utility) and conversion profiles; c) process temperature profiles $v s$ ratio $R$, utility flow rate over process flow rate.

The aim was just to show how DPT could be used as a way for selecting equipment according to various criteria.

This approach may be generalized. For instance, a collaborative project, named PROCIP and supported by the ANR (Prudhomme et al., 2013) is under progress, involving three industrial partners (Bluestar Silicones, Solvay-Rhodia, Processium) and three academic labs (Laboratoire de Génie Chimique - LGC, Laboratoire Réactions et Génie des Procédés - LRGP, Laboratoire de Génie des Procédés Catalytiques - LGPC). The aim is to develop an expert system guiding the equipment selection according to some specific criteria (process, chemicals, safety, and so on). The principle is as follows. A data-base is built and represents the software environment. This data-base consists in:

- the physico-chemical properties of the species (e-thermo $^{\mathrm{TM}}$, Processium);

- the equipment characteristics (pressure drop, residence time, heat and mass transfer performances via coefficients, viscous or solid handling, corrosion, and so on);
- the chemical reactions (stoechiometry, enthalpies, viscosity, density and so on).

These data may be either provided by the user, or estimated/calculated by the software, or already implemented. At the end of the day, the software is expected to propose a list of appropriate technologies with a quotation dependent on the predominance of a criterion over another.

\subsection{Conclusion}

In spite of its attractive and promising results, the PI methodology aforementioned (Fig. 1) exhibits a major default. Indeed, this methodology imposes a considerable effort of basic data acquisition and furthermore of simulation. Probably, it could be considered as a killer for the process development, because there is a crucial requirement for time-to-market reduction, particularly in the frame of process innovation in a very competitive world. 

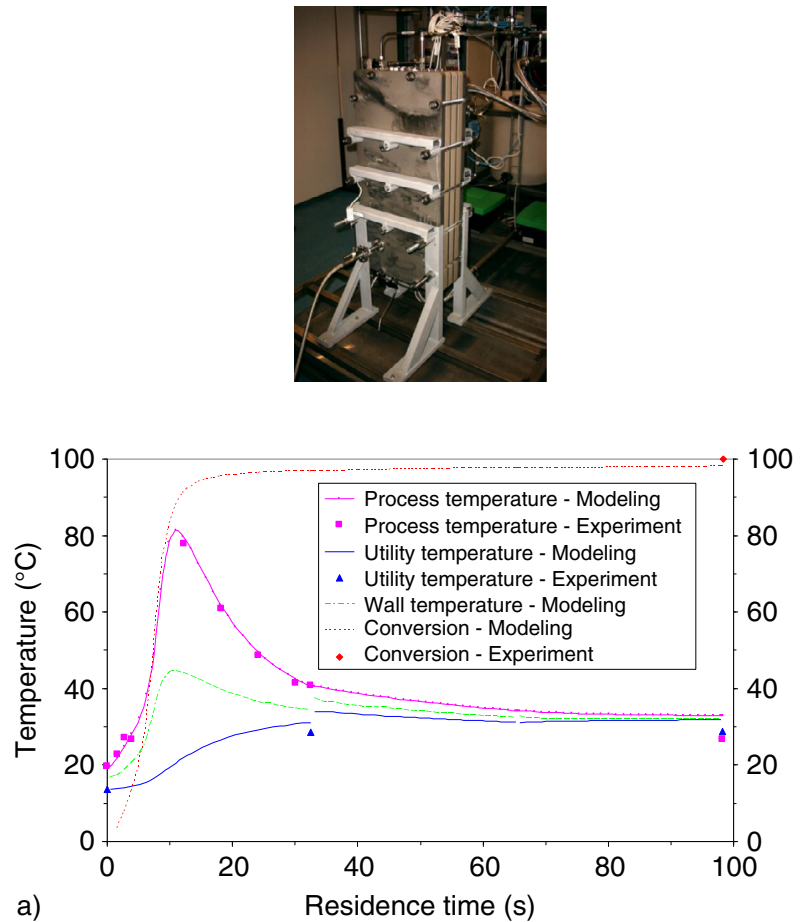

Figure 6

Temperatures (utility and process) and conversion profiles. a) Oxydation reaction in Alfa-Laval equipment; b) oxydation reaction in Boostec equipment.

It implicitly means that not only the process has to be intensified but also the way for intensifying it. There is nowadays a clear claim for innovative advances in experimental and methodology tools, while simulation tool remains a key issue with a continuous improvement of the solving techniques and of the computers (calculation times).

\section{INTENSIFICATION OF METHODS AND TOOLS}

\subsection{Introduction}

As previously said, there is a need for intensifying the methods and tools.

Concerning with the equipment characterization, and aiming at the objective of accelerating the technology selection, some platforms are born in Europe during these last years, able to provide some equipment benchmark studies in order to guide efficiently the choice of equipment and to perform also demonstration tests for the proof of concept. These platforms are either Private-Public-Partnership (PPP) structures or industrial ones. Among others, let's mention for instance:

- CMAC: EPSRC Centre for Innovative Manufacturing in Continuous Manufacturing and Crystallisation, UK;
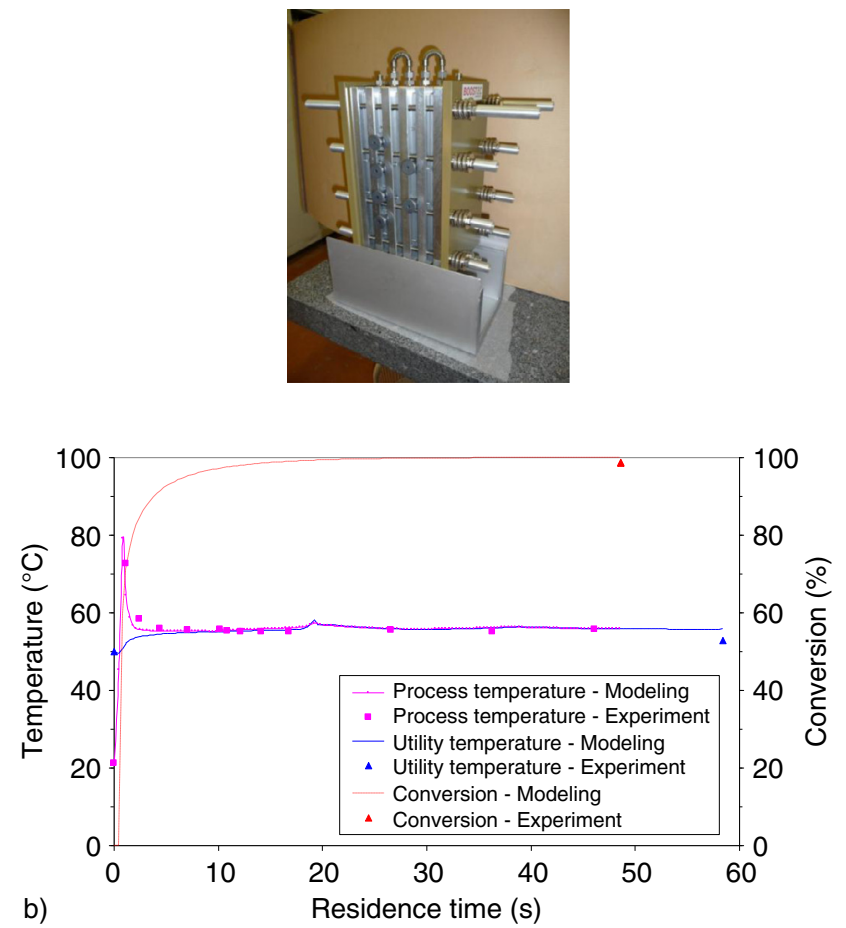

- CPI: Center of Process Innovation, UK;

- MEPI: Maison Européenne des Procédés Innovants, Toulouse, France;

- INVITE: Bayer Technology Services, Leverkusen, Germany.

Concerning with the chemistry characterization, the principle of High Throughput Experiments (HTE) at the labscale is now well admitted with different options developed in industry (Lab of the Future LOF, HTE-company) or solutions proposed by flow chemistry suppliers such as Vapourtech, Syrris, IMM, and so on.

The objective of all these tools is to reduce the time spent for the process development by offering services, methods or devices which allow the acquisition of the basic data required.

\subsection{Equipment Qualification}

Concerning the equipment qualification, benchmark studies have to be performed in view of comparing the technologies according to pressure drop, residence time distribution, heat and mass transfer performances, mixing efficiencies and so on. Some of the results arising from the benchmark studies performed in our lab are detailed in (Cabassud and Gourdon, 2010; Despènes et al., 2012; Elgue et al., 2014; Raimondi et al., 2014). 


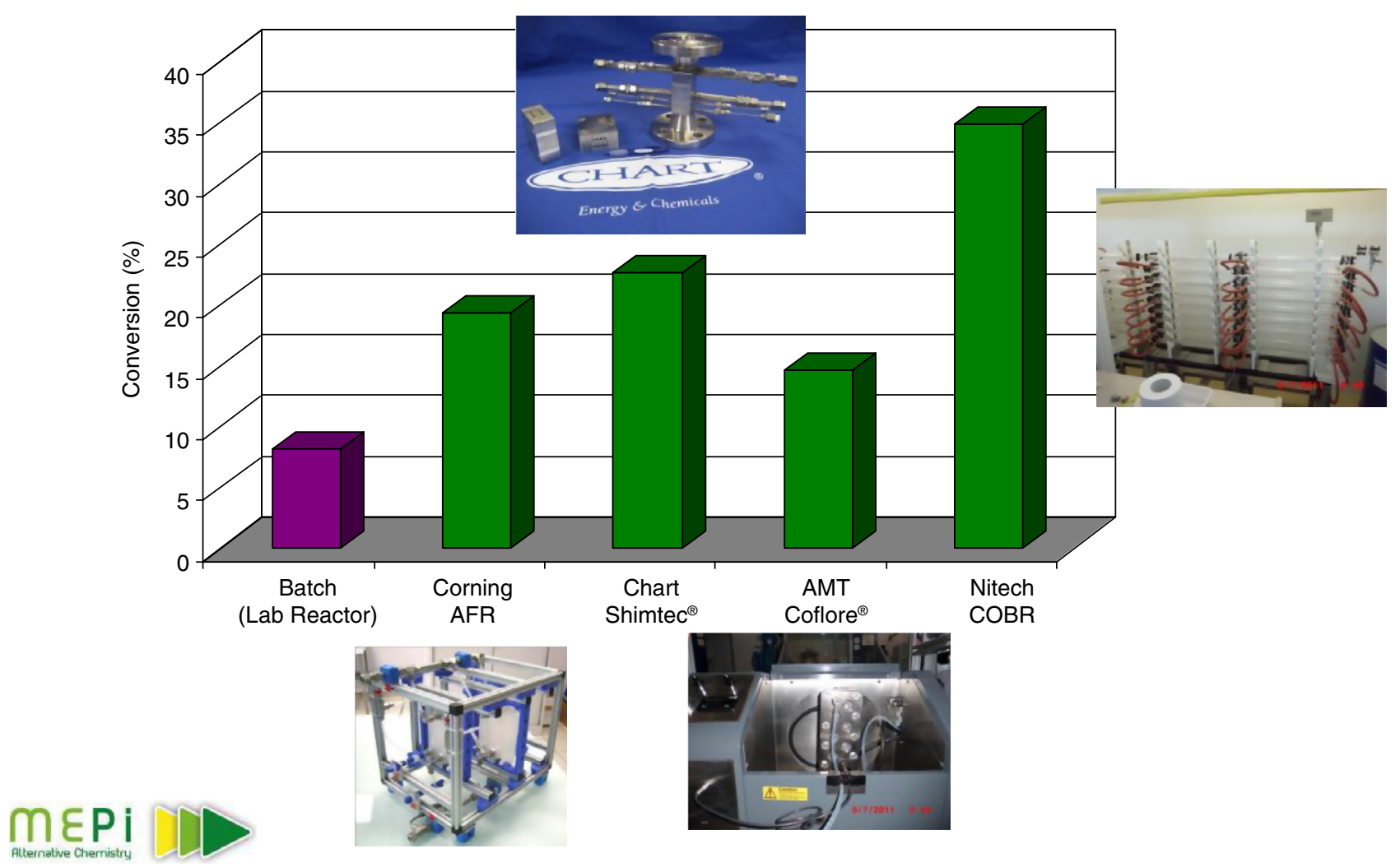

Figure 7

Benchmark study. Case of a liquid-liquid transfer limited reaction.

In order to emphasize a result of such a methodology, a benchmark study has been performed at the MEPI in Toulouse based on an esterification enzymic reaction (Elgue et al., 2014). The lipase-catalysed esterification of oleic acid with ethanol has been studied in various equipments (from lab Eppendorf to continuous reactors at pilot scale) leading to the same conclusions: this esterification is limited by liquid-liquid mass transfer. So the operation of this model reaction can be considered as an assessment of the liquidliquid mass transfer performances of every reactor, especially in terms of generation of interfacial area. As the species and the reaction involved here are easy to carry out, this constitutes an excellent test to characterise the mass transfer performances of different devices, such as: Corning G1 glass reactor, Chart Shimtec, Nitech COBR and $A M$ Technology Coflore. A given global residence time was applied $(140 \mathrm{~s})$, at a temperature of $30^{\circ} \mathrm{C}$, with a lipase concentration of $10 \mathrm{LU} / \mathrm{mL}$ (Lipase activity, in Lipase Unit per $\mathrm{mL}$ ) and a molar ratio between ethanol and oleic acid of 3 . This residence time of $140 \mathrm{~s}$ has been chosen according to the reactors investigated (Corning and Chart). In fact, regarding the volume of these reactors, such a residence time leads to flow rates which ensure optimal performances in terms of mass transfer and consequently reaction conversion. For COBR, the optimal amplitude and frequency have also been chosen as being those leading to the maximal conversion. Figure 7 illustrates the resulting comparison of mass transfer performances between the different equipments.

The Nitech COBR appears here the most efficient. Moreover, in such a device the possibility to reach high residence times (up to 100 minutes) also goes along with its enhanced mass transfer performances.

\subsection{Microfluidics, a Tool Dedicated to Process Intensification}

\subsubsection{Microfluidics: a HTE Tool}

Concerning the application characterization, i.e. the stoechiokinetics parameters, the phase equilibria data (for instance solubility) or the reaction enthalpies can be efficiently determined thanks to microfluidic devices. Some examples of microfluidic tool use are now available either in literature (Sarrazin et al., 2006, 2007; Pradère et al., 2006, 2010; Abgrall and Gué, 2007; Raimondi et al., 2008; Hany et al., 2010; 


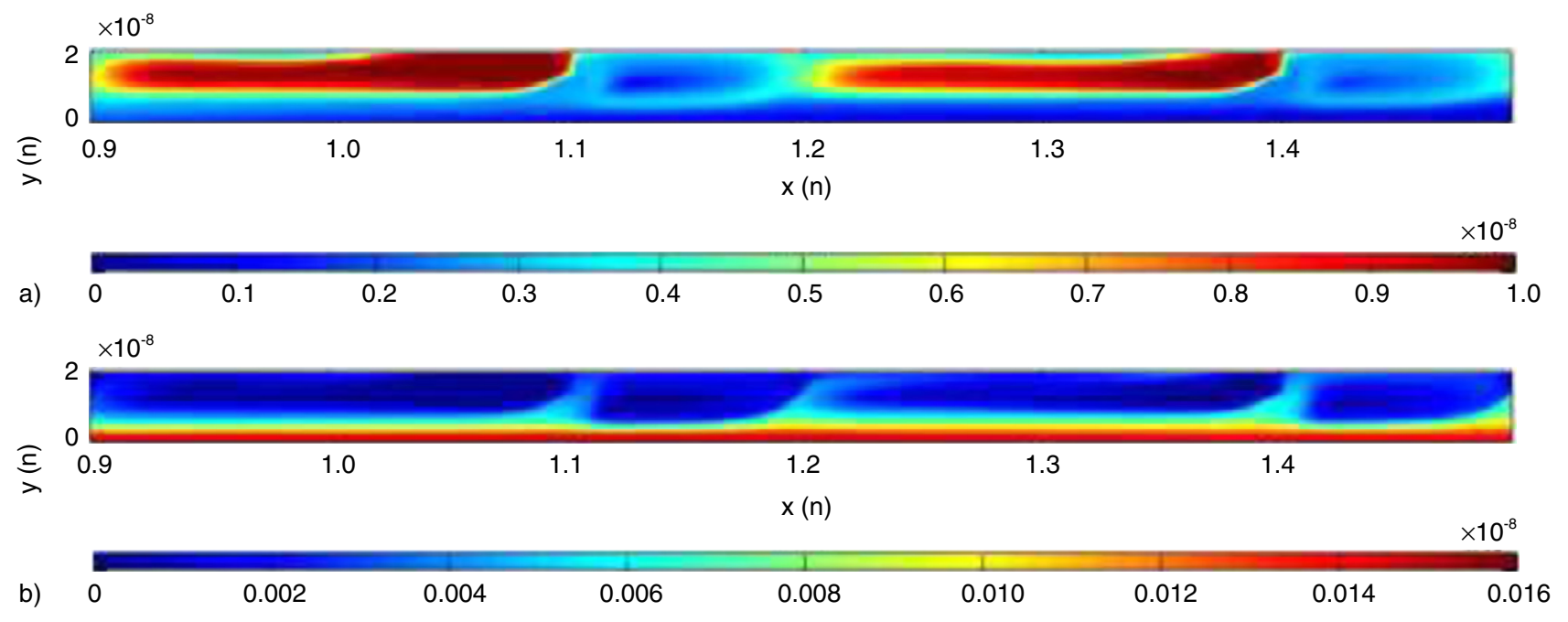

Figure 8

Concentration fields of reactant a) and by-product b) in a liquid-liquid reaction at $8 \mathrm{~ms}$ in a microchannel (Raimondi and Prat, 2011).

Ravey et al., 2012) or in the market (Syrris, Vapourtech, Uniqsis).

The principle of the "microdroplet reactor" as a perfectly mixed batch one is now well admitted and is applied to many different unit operations (Lörber et al., 2011; Mignard et al., 2011), including not only mixing and separation, but also precipitation or crystallization. It allows also to catch the chemical transformation at the early stages of the reaction (a few milliseconds), for instance illustrated in Figure 8 (Raimondi and Prat, 2011).

\subsubsection{Microfluidics: A Process Design Tool}

In some cases, thanks to a high quality information via FTIR, NIR (Richard et al., 2013a) and Raman spectroscopy (Dorobantu et al., 2012) on-line analysis, it is possible to use microfluidics as a process design tool. As example, the study of a transesterification reaction of vegetable oil (sunflower) with ethanol leading to ethyl esters, followed by a NIR technique at a microscale, allowed to propose a new operating mode based on a continuous process coupling the glycerol removal and the reaction equilibrium displacement (Richard et al., 2013b).

\subsubsection{Microfluidics: An Access to New Products}

Besides, new operating windows investigated at the microscale under better controlled conditions (plug flow, heat and mass transfer) allow eventually the access to new products, which is of great industrial interest.
For instance, the work performed by (Marcati et al., 2010) including droplet generation, polymerization, and particles handling (solvent change or particles encapsulation in microchannels) has allowed to generate complex solid structures (such as onion-like structures) pictured in Figure 9, which exhibits the different sizes and shapes obtained according to the flow rate of TriPropylene Glycol DiAcrylate (TPGDA), as reactive diluent.

\section{A CULTURAL BREAKTHROUGH}

Applying the "Lab-of-future" attitude is undoubtedly a good way for the development of innovative processes and presumably new products, but we are convinced that here is not only a technical challenge, but also a question of efficiently sharing the expertise and finally a question of knowledge dissemination. There is a need for new tools aiming with transferring the knowledge and diffusing the methodology of intensification.

Based on this statement, that the barriers are also cultural, three Universities (Delft, Dortmund, Toulouse) have decided to create in 2009 the EUROPIC network (www.europiccentre.eu). What is EUROPIC?

It is:

- an industrial community with common motivations in the field of Process Intensification, presently composed of 20 members from various sectors: Chemicals, Petchem, Fine-Pharma, Bio-Agro, Equipment and Engineering Services; 


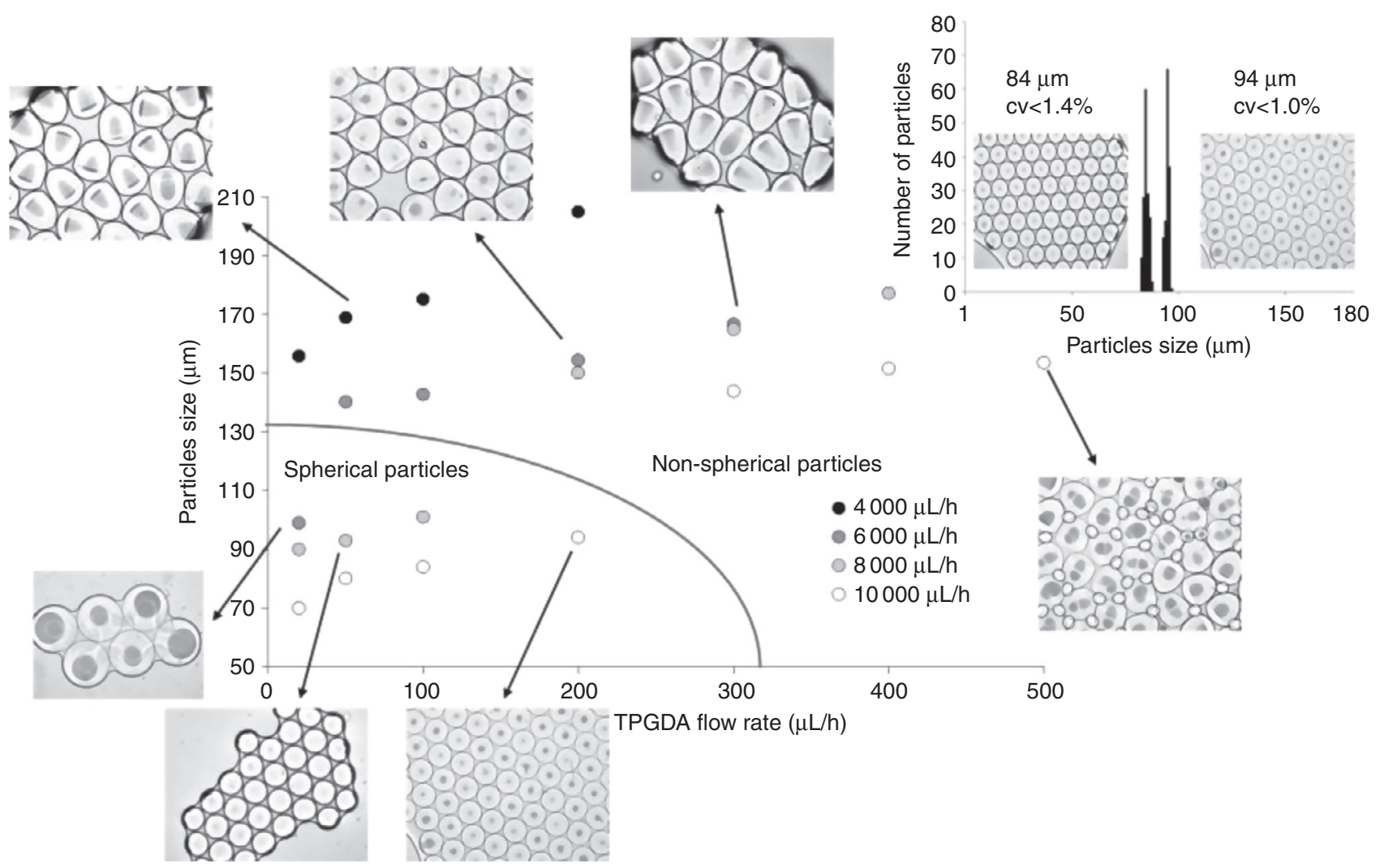

Figure 9

Cartography of particles obtained in a microchannel cross-junction (Marcati et al., 2010).

- an industry-driven platform for knowledge and technology transfer in PI;

- a club-like consortium based on the dissemination of highquality information: updated data-base, accreditated experts, industrial experts meetings, training courses on PI, and so on.

\section{CONCLUSION}

Process innovation thanks to PI is challenging and requires to develop breakthrough tools. The methodology proposed here intends to combine HTE microfluidic-based devices at the lab scale with simulation tools (DPT), for process designing, scaling-up and optimization. The following step is then the proof-of-concept thanks to demonstration platforms at the pilot scale (MEPI) in order to accelerate the knowledge transfer and the dissemination of success stories through networks (EUROPIC).

\section{ACKNOWLEDGMENTS}

A major part of the experimental facilities (at LGC and MEPI) were supported by the ANR, FNADT, Grand Toulouse, Préfecture Midi-Pyrénées and FEDER fundings.

\section{REFERENCES}

Abgrall P., Gué A.M. (2007) Lab-on-chip technologies: making a microfluidic network and coupling it into a complete microsystem - a review, J. Micromech. Microeng. 17, R15-R49.

Anxionnaz Z., Cabassud M., Gourdon C., Tochon P. (2010) Transposition of an Exothermic Reaction From a Batch Reactor to an Intensified Continuous One, Heat Transfer Engineering 31, 9, 788-797.

Benaïssa W., Gabas N., Cabassud M., Carson D., Elgue S., Demissy S. (2008a) Evaluation of an intensified continuous heatexchanger reactor for inherently safer characteristics, Journal of Loss Prevention in the Process Industries 21, 5, 528-536.

Benaïssa W., Elgue S., Gabas N., Cabassud M., Carson D., Demissy M. (2008b) Dynamic behaviour of a continuous heatexchanger/reactor after flow failure, International Journal of Chemical Reactor Engineering 6, A23, 1-19.

Boodhoo K., Harvey A. (2013) Process Intensification of Green Chemistry: Engineering Solutions for Sustainable Chemical Processing, ISBN: 978-0-470-97267-0.

Cabassud M., Gourdon C. (2010) Intensification of heat transfer in chemical reactors: heat exchanger reactors, in Novel concepts in catalysis and chemical reactors, by Cybulski A., Moulijn J.A., Stankiewicz A. (eds), Ed. Wiley.

Charpentier J.C. (2007) In the frame of globalization and sustainability, process intensification, a path to the future of chemical and process engineering (molecules into money), Chemical Engineering Journal 134, 84-92. 
Commenge J.M., Falk L. (2014) Methodological framework for choice of intensified equipment and development of innovative technologies, Chemical Engineering and Processing: Process Intensification 84, 109-127.

Cross W.T., Ramshaw C. (1986) Process Intensification - Laminar flow - heat transfer, Chemical Engineering Research and Design 64, 4, 293-301.

Cybulski A, Moulijn J.A., Stankiewicz A. (2011) Novel Concepts in Catalysis and Chemical Reactors: Improving the Efficiency for the Future, John Wiley \& Sons.

Despènes L., Elgue S., Gourdon C., Cabassud M. (2012) Impact of the material on the thermal behaviour of heat exchanger-reactors, Chemical Engineering and Processing : Process Intensification 52, 102-111.

Dorobantu Bodoc M., Prat L., Xuereb C., Gourdon C., Lasuye T. (2012) Online Monitoring of Vinyl Chloride Polymerization in a Microreactor Using Raman Spectroscopy, Chemical Engineering \& Technology 35, 4, 705-712.

Elgue S., Chopard F., Cabassud M., Cognet P., Prat L., Gourdon C. (2007) Optimisation of a chemical reaction in an open plate-type reactor, Patent EP1836627-A2.

Elgue S., Conté A., Gourdon C., Bastard Y. (2012) Direct fluorination of 1,3-dicarbonyl compound in a continous flow reactor at industrial scale, Chemica Oggi/Chemistry Today 30, 4.

Elgue S., Conte A., Marty A., Condoret J.S. (2014) Continuous lipase esterification using process intensification technologies, J. Chem. Technol. Biotechnol. 89, 10, 1590-1598.

European Process Intensification Roadmap (2007) Available in www.efce.info/efce_media/European_Roadmap_PI-p-531.pdf.

EUROPIC, European Process Intensification Centre, available in www.europic-centre.eu.

Hany C., Lebrun H., Pradere C., Toutain J., Batsale J.C. (2010) Thermal analysis of chemical reaction with a continuous microfluidic calorimeter, Chemical Engineering Journal 160, 3, 814-822.

Hellier P., Autret J.M., Despènes L., Elgue S., Gourdon C. (2010) Procédé de racémisation et d'acétylation de la leucine, Pierre Fabre Médicament, Patent FR1057629.

Lo S.N., Cholette A. (1972) Experimental study on the optimum performance of an adiabatic MT reactor, Canadian Journal of Chemical Engineering 50, 1, 71-80.

Lörber N., Sarrazin F., Guillot P., Panizza P., Colin A., Pavageau B., Hany C., Maestro P., Marre S., Delclos T., Aymonier C., Subra P., Prat L., Gourdon C., Mignard E. (2011) Some recent advances in the design and the use of miniaturized droplet-based continuous process: Applications in chemistry and high-pressure microflows, Lab on Chip 11, 779-787.

Marcati A., Serra C., Bouquey M., Prat L. (2010) Handling of Polymer Particles in Microchannels, Chemical Engineering Technology 33, 11, 1779-1787.

Martin S., Porcar R., Peris E., Burguete M.I., Garcia-Verdugo E., Luis S.V. (2014) Supported ionic liquid-like phases as organocatalysts for the solvent-free cyanosilylation of carbonyl compounds: from batch to continuous flow process, Green Chemistry 16, 3, 1639-1647.

MEPI, Maison Européenne des Procédés Innovants, available in www.mepi.fr.

Mignard E., Lörber N., Sarrazin F., Colin A., Pavageau B., Maestro P. (2011) Microfluidics: a new tool for research in chemistry, Actualité Chimique, Issue 353-54, 25-28.
Naumann E.B. (2002) Chemical reactor design, Optimization, and Scale-up, Mc Graw-Hill.

Pradère C., Joanicot M., Batsale J.C., Toutain J., Gourdon C. (2006) Processing of temperature fields in chemical microreactors with infrared thermography, QUIRT Journal 3, 1/2006, 117-135.

Pradère C., Hany C., Toutain J., Batsale J.C. (2010) Thermal analysis for velocity, kinetics, and enthalpy reaction measurements in microfluidic devices, Experimental Heat Transfer 23, 1, 44-62.

Prat L., Devatine A., Cognet P., Cabassud M., Gourdon C., Elgue S., Chopard F. (2005) Performance evaluation of a novel concept "Open Plate Reactor" applied to a highly exothermic reactions, Chemical Engineering Technology 28, 9, 1028-1034.

Processium, available in www.processium.com.

Prosim $^{\circledR}$, available in www.prosim.net/fr/index.php.

Prudhomme E., Osuna Sanchez H., Rousseaux P., Philippe R., De Bellefon C., Cabassud M., Gourdon C., Moreau M., Falk L., Lomel S., Baussaron L., Grollemund J., Durand N. (2013) PROCIP : une plateforme d'intensification de procédés, Récents Progrès en Génie des Procédés, ${ }^{\circ}$ 104, ISSN: 1775-335X ; ISBN: 978-2-910239-78-7, Ed. SFGP, Paris, France.

Raimondi N., Prat L., Gourdon C., Cognet P. (2008) Direct numerical simulations of mass transfer in square microchannels for liquid-liquid slug flow, Chemical Engineering Science 63, 5522-5530.

Raimondi N., Prat L. (2011) Numerical study of the coupling between reaction and mass transfer for liquid-liquid slug flow in square microchannels, AIChE Journal 57, 7, 1719-1732.

Raimondi N., Prat L., Gourdon C. (2014) Experiments of mass transfer with liquid-liquid slug flow in square microchannels, Chemical Engineering Science 105, 169-178.

Ramshaw C., Arkley K. (1983) Process Intensification by miniature mass transfer, Process Engineering 64, 1, 29.

Ravey C., Pradère C., Régnier N., Batsale J.C. (2012) New temperature field processing from IR camera for velocity, thermal diffusivity and calorimetric non-intrusive measurements in microfluidics systems, QIRT Journal 9, 1, 79-98.

Reay D., Ramshaw C., Harvey A. (2013) Process Intensification: Engineering for Efficiency, Sustainability and Flexibility, 2nd ed., Trevor Laird (ed.), Butterworth-Heinemann/IChemE, Woburn, ISBN 978-0-08-098304-2.

Richard R., Dubreuil B., Thiebaud-Roux S., Prat L. (2013a) On-line monitoring of the transesterification reaction carried out in microreactors using near infrared spectroscopy, Fuel 104, 318-325.

Richard R., Thiebaud-Roux S., Prat L. (2013b) Modelling the kinetics of transesterification reaction of sunflower oil with ethanol in microreactors, Chemical Engineering Science 87, 258-269.

Sarrazin F., Loubière K., Prat L., Gourdon C., Bonometti T., Magnaudet J. (2006) Experimental and numerical study of droplets hydrodynamics in microchannels, AIChE J. 52, 12, 4061-4070.

Sarrazin F., Prat L., Di Miceli N., Cristobal G., Link D.R., Weitz D. A. (2007) Mixing characterization inside microdroplets engineered on a microcoalescer, Chemical Engineering Science 62, 4, 1042-1048.

Shen Y., Maamor A., Abu-Dharieh J., Thompson J.M., Kalirai B., Stitt E.H., Rooney D.W. (2014) Moving from Batch to Continuous Operation for the Liquid Phase Dehydrogenation of Tetrahydrocarbazole, Organic Process Research and Development 18, 3, 392-401.

Stankiewicz A.I., Moulijn J.A. (2000) Process intensification: Transforming chemical engineering, Chemical Engineering Progress 96, 1, 22-34. 
Stankiewicz A.I., Moulijn J.A. (2003) Re-Engineering the Chemical Processing Plant: Process Intensification, CRC Press.

Syrris, Flow Chemistry Systems, available in www.syrris.com/.

Tsouris C., Porcelli J.V. (2003) Process intensification - Has its time finally come? Chemical Engineering Progress 99, 10, 50-55.

Uniqsis, Flow Chemistry, available in www.uniqsis.com.

Van Gerven T., Stankiewicz A.I. (2009) Structure Energy, Synergy,

Time - The Fundamentals of Process Intensification, Industrial and

Engineering Chemistry Research 48, 5, 2465-2474.
Vapourtech, Flow Chemistry, available in www.vapourtec.co.uk. Villermaux J. (1985) Génie de la réaction chimique : conception et fonctionnement des réacteurs, Lavoisier.

Manuscript submitted in May 2014

Manuscript accepted in November 2014

Published online in February 2015

Cite this article as: C. Gourdon, S. Elgue and L. Prat (2015). What are the Needs for Process Intensification? Oil Gas Sci. Technol 70, $3,463-473$. 